University of Wollongong

Research Online

Faculty of Social Sciences - Papers (Archive) Faculty of Arts, Social Sciences \& Humanities

2015

Popular culture: a support or a disruption to talent development in the lives of rural adolescent gifted girls?

Denise Wood

Charles Sturt University

Wilma Vialle

University of Wollongong, wvialle@uow.edu.au

Follow this and additional works at: https://ro.uow.edu.au/sspapers

Part of the Education Commons, and the Social and Behavioral Sciences Commons

Research Online is the open access institutional repository for the University of Wollongong. For further information contact the UOW Library: research-pubs@uow.edu.au 


\title{
Popular culture: a support or a disruption to talent development in the lives of rural adolescent gifted girls?
}

\begin{abstract}
Gifted adolescent rural girls live in a world where popular culture is a key source of information about their present and future lives. This study asked whether, as a key influence, popular culture supported or disrupted the talent development process of gifted adolescent girls in rural settings. Through an embedded case study approach this research study explored the responses of two groups of gifted adolescent girls to the messages presented to them in popular culture about talent development and giftedness. Data were generated predominantly through a series of focus groups and interviews. A narrative recount emerged after analysis of the recurring themes and stories. The study confirmed that, for girls, popular culture is a key source of influence on aspiration and identity, and that it tended to emphasise the importance of physical appearance and relationships. It identified popular culture as potentially both a disruption and a support to talent development for rural gifted girls. While popular culture was a key influence, it was not the only source of influence on young girls. The study concluded with a number of possible strategies for maximising the supportive aspects of popular culture while countering the disruptive elements.
\end{abstract}

\section{Keywords}

culture, support, disruption, talent, popular, development, adolescent, lives, rural, girls, gifted

\section{Disciplines}

Education | Social and Behavioral Sciences

\section{Publication Details}

Wood, D. \& Vialle, W. (2015). Popular culture: a support or a disruption to talent development in the lives of rural adolescent gifted girls?. Australasian Journal of Gifted Education, 24 (1), 13-22. 


\title{
Popular culture: A support or a disruption to talent development in the lives of rural adolescent gifted girls?
}

\author{
Denise Wood, Charles Sturt University, Bathurst, NSW \\ Wilma Vialle, University of Wollongong, NSW
}

\begin{abstract}
Gifted adolescent rural girls live in a world where popular culture is a key source of information about their present and future lives. This study asked whether, as a key influence, popular culture supported or disrupted the talent development process of gifted adolescent girls in rural settings. Through an embedded case study approach this research study explored the responses of two groups of gifted adolescent girls to the messages presented to them in popular culture about talent development and giftedness. Data were generated predominantly through a series of focus groups and interviews. A narrative recount emerged after analysis of the recurring themes and stories. The study confirmed that, for girls, popular culture is a key source of influence on aspiration and identity, and that it tended to emphasise the importance of physical appearance and relationships. It identified popular culture as potentially both a disruption and a support to talent development for rural gifted girls. While popular culture was a key influence, it was not the only source of influence on young girls. The study concluded with a number of possible strategies for maximising the supportive aspects of popular culture while countering the disruptive elements.
\end{abstract}

Keywords: Popular culture, gifted adolescent rural girls, talent development

In rural Australia, adolescent gifted girls, like all Australian girls, are establishing their identity through examining who they are, contemplating their future, and making choices towards achieving their goals. As gifted girls, they potentially have talents that are yet to be defined and developed. They experience influences that can support, or disrupt this development. Adolescents are immersed in a world that is described through, and in popular culture. Popular culture is the visual and textual information available for broad public consumption through media sources. These sources include material presented on television and visual texts such as movies, on the Internet in social media sites and in print magazines. For girls, a multitude of images and texts present portrayals of success, beauty, and popularity that often suggest ways of being a girl.

As young rural girls engage with diverse media sources and spend increasingly greater percentages of their time watching, listening and reading the available information, it is difficult to discern how popular culture influences their identity and aspirations. Images of beauty, power, and success contribute to stereotypes and become blurred in a collage of life possibilities (Inness, 2007). Adolescent girls use popular culture as a source of role models and guides, but the consistency of the messages may constrain girls in their aspirations. Popular culture can be a support for potential, providing information, ideas, and resources that inform young girls of their options and suggest new ways to be. But popular culture can also be a disruption to their development, confusing them, and positioning them in ways that cause them to deny their talent, or to hide it in order to fit in with the view of 'normality' (McRobbie, 2009).

Many girls face a dilemma where they feel forced to make a choice between the two options of giftedness and popularity (see also Gross, 1989). One of our participants commented, "Sometimes it is hard to choose whether to be beautiful or to be brainy" (Wood, 2015). Understanding the role of popular culture in this dilemma was the focus of the current study.

\section{The Messages in Popular Culture}

A key source of popular culture for the participants in this study was visual media, including movies and television. Visual media evolved as a social force over the twentieth century, informing the general population, and adolescents in particular, about life (Harris, 2004; Inness, 2007; Nash, 2006). Its role was to tell stories of lives both in the neighbourhood and across the world and to provide information for a diverse audience. The narratives re-told life and deconstructed it, challenging the social order, or reinforcing expectations and attitudes. Multiple sources presented the audience with conglomerate pictures of peoples' lives, 
connecting images in ways that generated fantasies that appeared to be real (Harris, 2004; Inness, 2007; Kearney, 2006; Nash, 2006). Young people were the focus of much of the content and young women were a key audience. Cultural changes that reflected feminist movements allowed young women the freedom and income to attend the cinema, purchase magazines, and subsequently purchase the products advertised (Nash, 2006).

In the mid-twentieth century, young girls developed a particular relationship with visual media (Cheu, 2007; Duits, 2010). Many of the images that girls engaged with reinforced traditional expectations and positioned them to aspire to have a standardised appearance, fashionable clothing, and a beautiful home (Cheu, 2007; Pipher, 2004). While some women characters showed independence and leadership, the same women were also portrayed as lonely and different (Zuckerman \& Dubowitz, 2005). Fictional young girls continued to seek a relationship and to defer to males. They were portrayed as being rescued by a male and having a life of home duties. Employment was a way of filling in time and few had a serious career (Zuckerman \& Dubowitz, 2005). Many of the creative activities that women engaged with were shown as home-centred, or amusing, while men in the mediated world were involved with the serious work (Signorelli, 1997). As audiences, young girls were provided with instructions of how to 'be' (Harris, 2004) and encouraged to actively take on the suggestions with catchphrases that described ways to behave and respond to the world.

In the latter half of the twentieth century, 'girl power' became the catchphrase of many adolescent girls (Duits, 2010; Harris, 2004; Pipher, 2004). Evoked originally by the images of popular music groups, such as 'The Spice Girls', this term generated a culture of potential, creating a sense that young girls had a power that would enable them to achieve in whatever area they aspired to master. 'The Spice Girls' represented a new form of talented behaviour, using their music to inspire girls to develop their talents, to perform and to grasp power (Fritzsche, 2004). They were followed by the appearance of a series of powerful young women on television and movie screens who continued to reinforce contradictory messages about behaviours and appearance (Inness, 2007).

These 'can do' girls broke social mores of behaviour and attitude, confronting males and other females, and often winning (Harris, 2004; Pipher, 1994). As mediated role models, they were sassy, confident, strong achievers, and leaders (Harris, 2004). However, their appearance remained consistent with traditional expectations, where beauty was equated with being thin, having blonde hair, and possessing stereotyped facial features (Martin \& Peters, 2005).

The Disney princesses, animated stars of multiple Disney productions, provided young girls with a consistent visual description of appearance and a set of behaviours across multiple movies and sets of merchandise (Cheu, 2007; Wohlwend, 2009) that positioned young women in a way that suggested that their happiness and success was dependent on a male. These beautiful young fictional women were supported by a thriving merchandising market, which allowed girls to role play the characters they were familiar with and to rehearse conversation and action, imitating and developing what they saw on the screen (Wohlwend, 2009). In other Disney movies, an older woman frequently mentored a young girl with a focus on changing her appearance or learning how to attract the male 'prince'. While there were some female characters who rebelled, were outspoken or different from the popular group, they were often rejected and either became isolates or the focus of bullying or ridicule (Charles, 2010; Duits, 2010; Harris, 2004).

Despite strong female characters in visual media, the plot lines and visual images continued to reinforce stereotyped expectations in terms of appearance and behaviour (Fabrianesi, J ones, \& Reid, 2008; McRobbie, 2009). A strong connection between media engagement and the reinforcement of traditional roles was identified across 120 studies that Ward and Harrison (2005) examined. The studies consistently showed that girls were influenced by the images in popular culture and aspired to both look like and behave in the same way as the women portrayed as a way of finding peer acceptance (Harper \& Tiggemann, 2007; Tiggemann, 2005, 2006; Tiggemann, Gardiner, \& Slater, 2003; Tiggemann \& Slater, 2003).

Popular culture was described as an influence on the lives of all adolescent girls. However, the literature did not differentiate the impact of popular culture on gifted girls, nor did it explore the messages that popular culture presented around talent development (Vialle, 2007).

\section{Giftedness and Talent Development}

While talent development has been discussed by a number of authors, models suggested by Gagné (2009), Kerr and Larson (2007), Noble, Subotnik and Arnold (1999) and Reis (1998) were particularly relevant to this research. Gagné's 
(1985, 2002, 2009) Model of Differentiated Giftedness and Talent (DMGT) identified both environmental and intrapersonal catalysts that influenced the process of talent development. It outlined a generic process that did not provide a gender-specific perspective. Three further models of talent development that explicitly considered the talent development of women emerged from retrospective studies with talented women (Kerr \& Larson, 2007; Noble et al, 1999; Reis, 1998) that influenced their talent development. Consistent elements in these models included a strong sense of identity, family support for activities that were nontraditionally feminine, a sense of passion and purpose for the talent domain, and a personal disposition of resilience and courage. Kronborg (2008, 2009) studied Australian eminent women, identifying salient influences and experiences in their lives that had supported their talent development. Her findings aligned with the earlier work. She described family allies (Kronborg, 2008) and passion for the talent domain (Kronborg, 2009) as important in the talent development process.

Gagné (2009) suggested that the environmental and intrapersonal catalysts could be positive or negative influences on the talent development process and thus either supported the process or disrupted it. None of the models in the literature identified popular culture explicitly as an influence on talent development. This meant that the impact that popular culture would have on the various catalysts and elements described as important had not been explored.

\section{Gifted Girls}

Vialle (2007) outlined a number of instances evident in popular culture where gifted girls were marginalised, bullied, or swayed to meet expectations of appearance and behaviour so as to be accepted. She concluded that "the gifted person tends to be portrayed as female, studious, not cool . . . may dumb down to achieve friendship, popularity or romantic success" (Vialle, 2007, p. 10). While gifted individuals have been studied in terms of their academic, socio-affective and emotional development (Neihart \& Betts, 2010; Vialle et al, 2007), gifted girls, as a sub-group, have been understudied (Bianco, Harris, Garrison-Wade, \& Leech, 2011; Reis, 1998). This resulted in a lack of understanding of the impact of gender on talent development (Kerr \& Larson, 2007; Kronborg, 2008).

Particular aspects of giftedness were identified in the literature as problematic for gifted girls. In many instances, girls achieve more successfully than boys in regular school life (Elwood, 2005; Freeman, 2003; Kronborg, 2009). They are more successful in examinations (Elwood, 2005) and more suited to typical classroom activity that includes passive learning and complicit behaviours (Kenway \& Willis, 1997; Mann, 1994; Mendez, 2000). However, Maxwell (2007) noted that girls who were identified as gifted felt pressure to achieve highly and to excel across disciplines, whereas boys tended to focus on one or two disciplines. These 'overachieving' girls set themselves higher goals and worked harder than boys (Elwood, 2005; Mendez, 2000). Teachers were less likely to nominate girls for gifted programs than boys and tended to describe gifted girls in more negative ways (Bianco et al, 2011; Petersen, 2013). They tended to focus on the social skills a girl displayed and the importance of these skills for success as a female (Bianco et al., 2011).

For some gifted girls, school was, and continues to be, a place where they have to 'dumb down' their responses to be socially accepted into the popular group of girls (Neihart \& Betts, 2010; Gross, 1998). They have to choose between meeting the expectations of others and fulfilling their personal aspirations (Skelton, Francis, \& Read, 2013). Some girls choose to act in a role that belies their ability, but allows them entry into conversations and social engagement (Renold \& Allen, 2006). Some researchers found that, due to increased pressure to perform well and to continue achieving highly, the motivation of gifted girls changed over the period of adolescence (Sanders \& Munford, 2008; Smutny, 2007; Walshaw, 2006). Schools provided gifted girls with restricted information about career options, which meant that girls experienced conflict between their aspirations and the ongoing advice they were given (Kerr \& Robinson Kurpius, 2004; Lea-Wood, 2004; Mendez, 2000).

\section{Rurality}

The study described in this paper was completed in a rural setting and the context of rurality was also discussed in the literature as an influence on the talent development of gifted individuals in adolescent years. Barriers to talent development named in the research included lower aspirations due to lower economic status, isolation, and lack of resources and opportunities (Alloway \& DallyTrim, 2008; Clark \& Zimmerman, 2001). The identification of gifted individuals was less consistent in rural areas due to lack of understanding about identification, limited resources, and reduced expectations for achievement, leading to lack of support or information about talent and giftedness (Montgomery, 2004; Pendarvis \& Wood, 2009). 
Gifted rural adolescents were influenced by their family to a greater extent than their urban peers (Schmitt-Wilson \& Welsh, 2012).

In rural contexts pressure was applied sometimes to support local business or community activity (Fan \& Chen, 1999). Lack of information and resources to provide different information limited the choices gifted adolescents felt they had (Alloway $\&$ DalleyTrim, 2008; Montgomery, 2004). For some gifted girls, the issue of leaving home and the subsequent changes this brought to their relationship with parents was also found to be a strong enough force to constrain the choices girls made (O' Quinn, 1999; Lea-Wood, 2004).

\section{Purpose of the study}

Despite the social changes over the last century that have seen increased opportunities for female independence and choice, the talent development of gifted adolescent girls has been mainly understood through retrospective studies of eminent women (Kerr \& Larson, 2007; Kronborg, 2008; 2009; Noble et al, 1999; Reis, 1998). Talent development models such as Gagné's DMGT (2009) provide a theoretical framework explaining talent development as a process influenced by catalysts in the environment and within the individual. These catalysts can be supportive, or disruptive. Neither gender nor rurality were identified as explicit catalysts by Gagné. Nor did his model of talent development, or the female-oriented models of Kerr and Larson (2007), Reis (1998), and Noble et al. (1999) respectively, identify popular culture as an influence on girls' talent development, even though there was a considerable focus in the broader literature on the impact popular culture had on all girls. This research explored whether popular culture was a support or a disruption to talent development, through the lived experience of gifted rural adolescent girls, which was an identified gap in the literature.

\section{Method}

This paper reports on part of a larger study undertaken as doctoral research to explore the impact that popular culture has on the talent development of gifted adolescent rural girls. The research was designed within a feminist paradigm, utilising constructivist methods of inquiry to explore ideas, concepts, and feelings with the participants in interactive, open, and descriptive discussions. An embedded case study, with two distinct cases, provided opportunity for close and detailed examination of the key research question: In what ways does popular culture support or disrupt the talent development of gifted adolescent rural girls?

\section{Participants}

In total, 31 girls from 12-16 years of age formed the case study groups. They came from two regional high schools in a regional centre in New South Wales, Australia. Case study group one consisted of 13 girls in Year 7/ 8 who had just commenced high school, coming from feeder primary schools in the local region. Case study group two consisted of 18 girls in Year 10/ 11, who were mid-way through their high school career. A limitation of the study was that neither school formally identified gifted students, which is common in public schools in NSW. When no other formal identification was available in a school setting, standardised test results were an adequate indicator of gifted academic performance (Vialle et al., 2007). After discussion in both schools, identification was made through the National Assessment Plan Literacy And Numeracy (NAPLAN) results from previous years and in-school anecdotal records of academic achievement to support the nominations. The girls had achieved in the top quartile of their year in both English and Mathematics. Except for three of the Year 7/ 8 girls who had participated in an Opportunity Class ${ }^{1}$ in their final year in primary school, the girls had not been previously formally identified as gifted learners.

\section{Data Collection}

Data were generated from a series of focus groups, formed as a Year 7/ 8 group and a Year 10/ 11 group in both schools, held over the first year of the study. Each group met four times at intervals of approximately six weeks during the year, during the school day and on school premises. Each focus group was guided by a series of questions, but developed freely from the flow of conversation initiated by the girls, allowing them to express their own ideas, build on those of others, and share insights as the discussion developed (Liamputtong \& Ezzy, 2005).

A second set of data was generated from a series of interviews with individuals or small groups who volunteered to participate in the second year of the study. Of the original group (31), 18 girls volunteered to participate in the interviews. The interviews commenced with an initial

\footnotetext{
${ }^{1}$ An Opportunity Class is a gifted class operating in NSW primary schools at Grades 5 and 6 . Admission to the class is through an academic selection test.
} 
analysis of the data from the focus groups, as a form of member check, and then the conversations were further developed with a set of semi-structured questions.

Each girl also maintained a journal during the first year of the study, logging engagement with popular culture and sharing personal commentary and insights. While these were not fully successful as data generation tools they provided rich, personal thoughts and some different perspectives. All participants also completed a personal profile and a timeline activity that illustrated their future aspirations and goals.

\section{Data Analysis}

The data were analysed using constructivist grounded theory (Charmaz, 2006). The analysis sought to construct a narrative that encapsulated the stories, thoughts, and feelings of the participants, and wove them into themes that were consistent and that provided responses to the research question. Patterns were identified in the focus group transcripts and then triangulated with patterns found in both the interview data and the journal entries. The profiles and timelines provided further detail of the way the girls saw their talent developing and were also used to confirm the patterns that emerged. The final narrative recount provides a rich description of the lived experience of gifted adolescent rural girls and their interactions with popular culture, in the context of its support or disruption of their talent development.

\section{Results}

\section{Defining Popular Culture}

The girls defined popular culture in the following ways, reflecting the ways they engaged with it:

Music and other people's cultures and readings . . . the things other people do (Focus group 1, School A, Year 7/8)

Stuff that's important in Australia and teenagers are interested in . . . music, the computer and technology (Focus group 1, School B, Year 7/ 8)

Celebrities having an effect on us ... . the way we see celebrities and models and how we feel about ourselves looking at people like that. (Focus group 1, School A, Year 10/11)

Like fashion, and how you dress, and how everybody sees you ... . (Focus group 1, School B, Year 10/ 11)
Overall, the definitions included literature, fashion, trends, hairstyles, handbags, television shows, movies, music and magazine articles, covers, and images. The girls recognised that it reflected the context, noting that J apanese characters looked different to those created in the western world. The older girls had studied popular culture as a topic in school but were happy to explore it differently and personally in the focus groups. The Year 7/ 8 girls were highly critical of aspects of popular culture such as airbrushed images, though often their responses demonstrated that, while they critiqued it, they also avidly read it and believed what they read.

All the girls were very familiar with a range of popular culture sources: engaging with visual media including movies and television, print media including magazines, and music videos and recordings. Their logs showed that they engaged with popular culture daily and in the company of friends and family, as well as alone. It was something they interacted with when sick, for homework and for social exchanges. These girls talked about the internet and social media sites such as Facebook, BeBo and Twitter but identified these as an opportunity to communicate and share with peers, rather than as a source of popular culture. They were aware of the dangers of including 'random' people who were not immediate friends on their lists, but also noted how it allowed them to maintain contact with people they met through sport or social events and with family members in different geographical locations.

Popular culture was recognised as a source of influence on how girls understood themselves and the world, as highlighted in the following comments from the Year 10/11 girls:

It tells you what is cool and what's not . . . what the people on the TV like and things you kind of think . . . mean . . . I have to like it too . . . whatever they do you kind of think that must be better and that must be the right thing to do. (Interview, Year 10/ 11, School $A, M \& R)$

I think it sort of starts when you see them with all the nice clothes that you want, 'if I had a lot of money and I was like her I could have all those clothes. . . the older you get you sort of realise it's not how everyone in the world lives. . . it's not really reality. (Focus group 1, School B, Year 10/11)

Popular culture provided them with ideas about clothing, relationships, people, and careers. It connected them to different worlds. Because so many movies and television shows for adolescents are based around everyday life - the shopping mall and school events - they could 
identify with what was happening and see similarities between their lives and the lives of the fictional characters they knew. Year 7/ 8 girls in particular talked about the characters and plot lines in depth, but sometimes it was difficult to discern whether they were talking about real people they knew or the characters. Their conversation was driven by popular culture material. By Year 10/ 11 this was less evident in their conversation and they showed greater interest in the way the media reflected life or suggested other ways to be.

\section{The influence of popular culture}

The girls were able to recognise how they were influenced by messages in popular culture. They identified that they were questioning how closely they needed to follow the images and messages and that it impacted on their self-image, as indicated in the following comments:

Popular culture is based around how you look, whether it be makeup . . . your face and your hair . . . how slim you are ... (Interview, Year 7/ 8, School A, L\&S)

People call me pretty skinny, but then you look at other girls and I think, "No, compared to them in the magazine and I'm not". It doesn't always make you feel good about yourself. It makes you feel pretty bad about yourself (Interview, Year 10/ 11, School B, $M \& R$ )

\section{Giftedness and popular culture}

The girls expressed concern at the way intelligent people were represented in popular culture as they made statements such as: I don't think they make smart people anymore, because in movies smart people are always nerds, and they have to make cool people, so they're always dumb. (Focus group 3, Year 7/8, School B)

This comment reflected the way they felt that gifted girls were often depicted as quirky, clumsy, or the odd one out in the group. In another conversation the following comment was made:

Most of the time in movies, they make it stereotypical . . . it's like the smart people are usually like the nerds, like at the bottom . .. (Focus group 2, School A, Year 7/8)

They noticed that usually the male in a movie or show was the one who was recognised for his intelligence or skill: Why does the man have to be the intelligent one? (Interview, Year 7/8, School $A, L \& S$ ) and felt that this did not encourage girls to show their intelligence or to aspire to achieve academically.

When asked to consider how a gifted character could be constructed in popular culture to represent themselves as gifted individuals, the terms they used included 'normal', 'like me', 'kind', 'caring', 'with friends', 'happy', 'no glasses'. The girls saw themselves as normal adolescents, although they also noted that they were aware of their ability to achieve academically. Most of these girls had been aware of differences between themselves and other girls during their school lives. They did not believe that the way gifted girls were portrayed in popular culture represented who they were as gifted girls.

There were some characters they identified with in the media who they knew were gifted. One was Coco Chanel, whose life had been described in a documentary watched by one of the Year 10/ 11 girls. She responded to it with the following comment:

She wasn't at all stunningly beautiful, she was pretty plain . . . the way that they portrayed her personality was what made her, you could sense that she was intelligent and an incredible woman. (Focus group 3, School A, Year 10/11)

Another mention of a positive image emerged as they discussed women scientists in television shows based on criminal investigations. These shows generally included both male and female leads, who worked together to solve crimes. The team was a mixture of confident women with a traditional appearance, perhaps the 'can-do' women of popular culture, as well as an unusual, quirky woman who was not the key character but rather a strong support and a contrast to the other woman. As the girls spoke about one of these women, they described her as follows:

$P$ : She's a scientist and she figures everything out . . . she does the entire DNA screening. $P$ : She's cool.

$P$ : In a different way. (Focus group 3, School

A, Year 7/ 8)

Other girls referred to the fact that they did not believe gifted individuals would be very interesting to watch because of their personality (if they were just smart, then . . . you don't really want to watch (Focus group 2, School B, Year 10/ 11)). They also perceived that popular culture was:

trying to tell us to use our intelligence, to plot against others rather than aspire to be smart or go onto uni . . . it's telling us just to play it against each other and not be very nice' (Interview, Year 10/ 11, School A, M\&R). 
The data revealed that the girls noticed two contrasting ways of talent development and achievement being represented in popular culture. Popular culture provided them with images of different ways to be and of different careers that utilised different types of intelligence. This view was illustrated by these comments in an interview:

Popular culture ... has developed the idea of what we, both smart people, and what intelligence can lead to. Without popular culture we wouldn't be able to see the contrasts . . . popular culture has led us to believe that being a doctor or a scientist . . . those things require a massive amount of intelligence. Whereas we all have thought that being a musician or whatever, it is just like you need the right ticket. (Interview, Year 10/ 11, School A, H\&B)

It's the same with stuff like PR and public relations ... in order to do that you need to know people and in order to actually run a successful business ... you need to be able to a) know people and b) know the trends. (Interview, Year 10/11, School A, H\&B)

In contrast, the girls had also noticed that popular culture continued to suggest that girls were not intelligent and that if they were, they would not fit in. When watching television images or reading magazines focussed on appearance and body image the girls were often reminded that success was often defined by the clothing and physical appearance of the women in popular culture. It was described in a conversation in this way:

Everything you watch, the girls have to be stupid and that's just how it is. And the smart ones are always looked down upon by males and things like that. (Focus group 2, School B, Year 10/11)

\section{Discussion}

Over the course of the research, the focus group conversations and interviews revealed a depth of thinking and responding to popular culture, as well as a naiveté of response that implied the girls simply saw popular culture as entertainment and its influence on their thinking happened without their full awareness. The older girls were more critically aware of the power of popular culture to provide them with instructions for being. However, even they admitted that they were sometimes 'sucked in' by the many images they saw.

There were three discrete ways that the girls responded to the presence of popular culture in their lives. Both case study groups, but in particular the Year 7/ 8 girls, responded literally, believing what they saw, being entertained by it and spending much of their time discussing the images, articles, characters, and plot lines. Popular culture offered an escape and a source of connection with friends as they recounted the stories. Such uncritical absorption of aggregated stories and images could lead to some confusion as adolescent girls sought role models for identity building (Duits, 2010; Harris, 2004).

A second way of responding was critical. Here the girls took a critical stance and viewed the images and messages with mistrust. They knew about the techniques used to manipulate images for perfection; this had led to an overall lack of trust with any information and a hesitation to believe what they saw. This view suggested that popular culture positioned young girls to have limited choices in their lives, an idea also discussed in the literature (Dohnt \& Tiggemann, 2006; Tiggemann \& Slater, 2003).

The third way the girls responded to what they saw in popular culture was emotive, when they empathised with the pressure placed on celebrities who were frequently in the media and whose lives were interrupted by cameras and text. They expressed considerable concern that popular culture had created high expectations of access by the audience for media. This response had not been evident in the literature that considered the impact of popular culture on young girls.

The way the girls respond to popular culture overall does not, of itself, indicate whether popular culture supports or disrupts talent development. Each model of talent development included a number of catalysts or elements that, together, influenced the achievement of talent. Gagné (2009) suggested that an individual filters environmental influences through their own worldview and sense of self. This worldview then supports the developmental process that is ongoing through the talent development process. Kerr and Larson (2007) identified the need for a strong sense of self and a number of external supports including family and friends that were needed for talent development. Reis (1998) expressed the importance of personal purpose and drive while Noble et al. (1999) identified that effective talent development could result in talent being displayed at either a local or a global level. This means that talented individuals do not only have to strive for fame or eminence on a world platform but rather can utilise their talent at a local level, in their own rural community. This view of talent performance intersects with the pressure to stay locally that has been identified in rural settings when talented individuals perceive greater opportunity 
in urban areas (O' Quinn, 1999; Schmitt-Wilson \& Welsh, 2012), as well as suggesting a balance for women between family, career, and achievement.

Given these views of talent development, and the responses of the girls in the study to popular culture in their lives, as well as the influence it has on their view of women, giftedness, and success, this study has demonstrated that popular culture is potentially both a support and a disruption to the talent development of rural gifted adolescent girls.

The girls perceived that popular culture suggested that appearance, being thin and possessing traditional beauty should be a priority in their lives, to continually work at and maintain. It suggested that fashion was vital to success and that successful women manipulated those around them to achieve their goals. These perceptions were supported in the literature (Fabrianesi et al, 2008; Harper \& Tiggemann, 2007; Martin \& Peters, 2005; Signorelli, 1997). Few role models among the celebrity icons or fictional characters provided these young girls with examples of talented women who achieved with 'ordinary' looks and appearance.

Talented women in popular culture were not portrayed as striving for academic success, or showing effective leadership. The effort and time needed to achieve academically, acclamations for academic achievements and positive views of academic work were absent. Tiggemann et al. (2003) suggested that academic achievement was not valued as much as clothing size and this was reinforced when the girls in this study identified that they did not receive the message that academic skills and behaviours were valued or admired. Because many women continued to be shown in traditional homekeeping activities, or in minor roles (Zuckerman \& Dubowitz, 2005), popular culture potentially disrupts talent development because it does not appear to value the focussed, concentrated effort, in traditional as well as non-traditional or diverse areas, that talented girls need in order to feel confident to tackle challenging careers. The literature suggested that gifted adolescent girls needed support in considering their futures through explicit career advice and information, but did not identify popular culture as a factor in career indecision (Lea-Wood, 2004; Kerr \& Robinson-Kurpius, 2004; Maxwell, 2007; O' Quinn, 1999).

However, popular culture potentially offered some support for the talent development of gifted rural adolescent girls, even though this had not necessarily been identified in the literature. The girls noted how popular culture offered them windows into different worlds, visions of careers that they did not have access to in their rural location, and women who were accepted because of their capabilities and skills. It suggested different career pathways from those normally available in rural settings and it opened the world of travel through showing different locations and contexts. The role models and ideas they were able to access in some areas of popular culture could potentially help gifted rural adolescent girls make choices outside of the normal ones for their community.

\section{Conclusion}

Popular culture is potentially both a support and a disruption to talent development. It needs to be acknowledged as an influence on talent development, but it is one of a number of influences that impact on a girl's emerging identity as a talented individual.

To most effectively utilise what is offered on the big screen, the television, in the images and articles in magazines and the ways of being displayed in music videos, adolescent rural girls need the skills to critique and recognise the problematic messages. Popular culture will remain a key part of their lives, bringing them conglomerate images of lives lived in ways very different to their rural context. Their environment needs to provide them with alternate ways of being. Female role models who have taken difficult pathways to meet the challenges of giftedness and success in key fields of endeavour can counter the non-academic role models prevalent in popular culture. Programs can be devised that develop critical literacies that enable girls to understand how they are influenced by popular culture and provide them with the knowledge to understand that successful talent achievement does not always mean becoming widely recognised and part of the popular culture world. Beauty, a stereotypical appearance, fame, and celebrity are not essential for successful talent development, despite the prevalence of these messages in popular culture.

\section{References}

Alloway, N., \& Dalley-Trim, L. (2008). 'High and dry' in rural Australia: Obstacles to student aspirations and expectations. Rural Society, 19(1), 49-59.

Bianco, M., Harris, B., Garrison-Wade, D., \& Leech, N. (2011). Gifted girls: gender bias in gifted referrals. Roeper Review, 33(3), 170-181.

Charmaz, K. (2006). Constructing grounded theory: A practical guide through qualitative analysis. Thousand Oaks, CA: Sage Publications. 
Cheu, H. F. (2007). Disney and girlhood. In C. A. Mitchell \& J. Reid-Walsh (Eds.), Girl culture: An encyclopedia [two volumes] (pp. 48 - 56). Westport, CT: Greenwood Publishing Group.

Clark, G., \& Zimmerman, E. (2001). Identifying artistically talented students in four rural communities in the United States. Gifted Child Quarterly, 45(2), 104-114. doi: 10.1177/001698620104500204

Dohnt, H. K., \& Tiggemann, M. (2006). The contribution of peer and media influences to the development of body satisfaction and self-esteem in young girls: A prospective study. Developmental Psychology, 42, 929-936.

Duits, L. (2010). The importance of popular media in everyday girl culture. European J ournal of Communication, 25(3), 243-257. doi: $10.1177 / 0267323110373461$

Elwood, J. (2005). Gender and achievement: What have exams got to do with it? Oxford Review of Education, 31(3), 373-393.

Fabrianesi, B., Jones, S. C., \& Reid, A. (2008). Are pre-adolescent girls' magazines providing ageappropriate role models? Health Education, 108(6), 437-449.

Fan, X., \& Chen, M. J . (1999). Academic Achievement of rural school students: A multi-year comparison with their peers in suburban and urban schools. J ournal of Research in Rural Education, 15(1), 3146.

Freeman, J. (2003). Gender differences in gifted achievement in Britain and the US. Gifted Child Quarterly, 47(3), 202-211. doi: $10.1177 / 001698620304700304$

Fritzsche, B. (2004). Spicy strategies: Pop feminist and other empowerments in girl culture. In A. Harris (Ed. ), All about the girl: Culture, power and identity (pp. 155-162). New York: Routledge.

Gagné, F. (1995). From giftedness to talent: A developmental model and its impact on the language of the field. Roeper Review, 18(2), 103123. doi: $10.1080 / 02783199509553709$

Gagné, F. (2009). Building gifts into talents: Detailed overview of the DMGT 2.0. In B. MacFarlane $\&$ T. Stambaugh (Eds.), Leading change in gifted education: The festschrift of Dr. J oyce VanTasselBaska (pp. 61-80). Waco, TX: Prufrock Press.

Gross, M. U. M. (1989). The pursuit of excellence or the search for intimacy? The forced-choice dilemma of gifted youth. Roeper Review, 11(4), 189-194.

Gross M. U. M. (1998). The "me" behind the mask: Intellectually gifted students and the search for identity, Roeper Review, 20(3), 167-174. doi: $10.1080 / 02783199809553885$

Harper, B. , \& Tiggemann, M. (2007). The effect of thin ideal media images on women's selfobjectification, mood, and body image. Sex Roles, 58(9), 649-657. doi: 10.1007/ s11199-007-9379-x

Harris, A. (2004). Future girl: Young women in the twenty-first century. New York, NY: Routledge.

Inness, S. A. (2007). Introduction: Who remembers Sabrina? Intelligence, gender, and the media. In S. A. Innes (Ed.), Geek chic: Smart women in popular culture (pp. 1-10). New York, NY: Palgrave Macmillan.

Kearney, M. C. (2006). Girls make media. New York, NY: Routledge.
Kenway, J ., \& Willis, S. (1997). Answering back: Girls, boys and feminism in schools. Sydney, NSW: Allen and Unwin.

Kerr, B. A. (1997). Smart girls: A new psychology of girls, women and giftedness. Scottsdale, AZ: Gifted Psychology Press.

Kerr, B. A., \& Larson, A. (2007). How gifted girls become eminent women. In S. Lopez (Ed.), Positive psychology perspectives. New York, NY: Praeger.

Kerr, B., \& Robinson Kurpius, S. E. (2004). Encouraging talented girls in math and science: effects of a guidance intervention. High Ability Studies, 15(1), 85-102.

Kronborg, L. (2008). Allies in the family contributing to the development of eminence in women. Australasian J ournal of Gifted Education, 17(2), 514.

Kronborg, L. (2009). Passionate engagement in domains contributes to eminent women's talent development. Australasian J ournal of Gifted Education, 18(1), 15-24.

Lea-Wood, S. S. (2004). Factors influencing the vocational decisions making of higher ability adolescent girls (Unpublished doctoral dissertation). University of Melbourne, Melbourne.

Liamputtong, P., \& Ezzy, D. (2005). Qualitative research methods ( 2 nd ed.). South Melbourne, VIC: Oxford University Press.

Mann, J. (1994). The difference: Discovering the hidden ways we silence girls - finding alternatives that can give them a voice. New York, NY: Warner Books, Inc.

Martin, M. C., \& Peters, C. O. (2005). Exploring adolescent girls' identification of beauty types through consumer collages. J ournal of Fashion Marketing \& Management, 9(4), 391-406.

Maxwell, M. (2007). Career counselling is personal counselling: A constructivist approach to nurturing the development of gifted female adolescents. Career Development Quarterly, 55(3), 206-224.

McRobbie, A. (2009). The aftermath of feminism: gender, culture and social change. Los Angeles: Sage.

Mendez, L. M. R. (2000). Gender roles and achievement-related choices: A comparison of early adolescent girls in gifted and general education programs. J ournal for the Education of the Gifted, 24(2), 149-169.

Montgomery, D. (2004). Broadening perspectives to meet the needs of gifted learners in rural schools. Rural Special Education Quarterly, 23(1), 3-16.

Nash, I. (2006). American Sweethearts: Teenage girls in twentieth century popular culture. Bloomington, Indiana: Indiana University Press.

Neihart, M. , \& Betts, G. T. (2010). The revised profiles of the gifted and talented: A research based approach. Retrieved from http:// www. ingeniosus. net/ wp-content/ uploads / 2010/ 11/ PROFILES-BEST-REVISED-MATRIX-2010. pdf

Noble, K. D., Subotnik, R. F., \& Arnold, K. D. (1999). To thine own self be true: A new model of female talent development. Gifted Child Quarterly, 43(4), 140-149. doi: 10.1177/001698629904300302

O'Quinn, M. D. (1999). Getting above our raising: A case study of women from the coalfields of southwest Virginia and eastern Kentucky. J ournal of Research in Rural Education, 15(3), 181-189. 
Pendarvis, E., \& Wood, E. W. (2009). Eligibility of historically underrepresented students referred for gifted education in a rural school district: A case study. J ournal for the Education of the Gifted, 32(4), 495-514.

Petersen, J. (2013). Gender differences in identification of gifted youth and in gifted program participation: a meta-analysis. Contemporary Educational Psychology, 38(2013), 342-348.

Pipher, M. (1994). Reviving Ophelia: Saving the selves of adolescent girls. NY: Riverhead Books.

Reis, S. M. (1998). Work left undone. Mansfield Centre, CT: Creative Learning Press, Inc.

Sanders, J., \& Munford, R. (2008). Losing self to the future? Young women's strategic responses to adulthood transitions. J ournal of Youth Studies, 11(3), 331-346.

Signorelli, N. (1997). Reflections of girls in the media: A content analysis. A study of television shows and commercials, movies, music videos and teen magazine articles and ads. Oakland, CA: Henry J . Kaiser Family Foundation.

Skelton, C., Francis, B., \& Read, B. (2013). "Brains before 'beauty' ?" high achieving girls, school and gender identities. Educational Studies, 36(2), 185194.

Smutny, J. F. (2007). Reclaiming the lives of gifted girls and women. Unionville, NY: Royal Fireworks Press.

Tiggemann, M. (2005). Television and adolescent body image: the role of program content and viewing motivation. Journal of Social and Clinical Psychology, 24(3), 361-381.

Tiggemann, M. (2006). The role of media exposure in adolescent girls' body dissatisfaction and drive for thinness: Prospective results. J ournal of Social and Clinical Psychology, 25(5), 523-541.

Tiggemann, M., Gardiner, M., \& Slater, A. (2003). “I would rather be a size 10 than have straight $A^{\prime} s^{\prime \prime}$ : A focus group study on adolescent girls' wish to be thinner. J ournal of Adolescence, 23(6), 645-659.
Tiggemann, M., \& Slater, A. (2003). Thin ideals in music television: A source of social comparison and body dissatisfaction. International J ournal of Eating Disorders, 35(1), 48-58. doi: 10.1002 / eat. 10214

Vialle, W. (2007). Pink or Paris? Giftedness in popular culture. Australasian J ournal of Gifted Education, 16(1), 5-11.

Vialle, W., Heaven, P. C. L. , \& Ciarrochi, J. (2007). On being gifted, but sad and misunderstood: Social, emotional and academic outcomes of gifted students in the Wollongong Youth study. Educational Research and Evaluation, 13(6), 569586. doi: 10.1080/ 13803610701786046

Walshaw, M. (2006). Girls' workplace destinations in a changed social landscape: Girls and their mothers talk. British J ournal of Sociology of Education, 27(5), 555-567.

Ward, L. M. , \& Harrison, K. (2005). The impact of media use on girls' beliefs about gender roles, their bodies, and sexual relationships: A research synthesis. In J. H. Daniel \& E. Cole (Eds.), Featuring females: Feminist analyses of media (pp. 3-23). Washington, DC: American Psychological Association.

Wohlwend, K. E. (2009). Damsels in discourse: Girls consuming and producing identity texts through Disney princess play. Reading Research Quarterly, 44(1), 57-83. Retrieved from dx. doi. org/ 10.1598/ RRQ. 44.1.3

Wood, D. (2015). Beauty or brains? The impact of popular culture on the development of adolescent rural gifted girls' identity and subsequent talent development. Unpublished Doctoral thesis, University of Wollongong, NSW, Australia.

Zuckerman, D., \& Dubowitz, N. (2005). Clash of cultures: Women and girls on TV and in real life. In J. H. Daniel \& E. Cole (Eds.), Featuring females: Feminist analyses of media (pp. 59-69). Washington, DC: American Psychological Association.

\section{Contact details}

\section{Dr Denise Wood}

Charles Sturt University, Bathurst

Phone: +61263348698

Email: dwood@csu.edu.au

\section{Biographical details}

Denise Wood is a Lecturer in Teacher Education at Charles Sturt University in Bathurst teaching into primary and early childhood education courses. She has been involved in the gifted education field since the early $90 \mathrm{~s}$, as both a parent and an educator. During that time she has been the president of the NSWAGTC, and the editor of the children's section in the journal, Gifted. Denise has worked with schools in different sectors, providing inservice education around gifted children for teachers and parents. Having just completed her doctoral study focussed on rural gifted girls and the impact popular culture has on their talent development, she is looking forward to continuing work in the area of rural gifted children and their talent development.

Wilma Vialle is currently a Professor in Educational Psychology and Associate Dean International at the University of Wollongong. Her work is strongly focused on gifted education and she has published extensively in this field. Wilma's research interests focus on maximising intellectual potential and she is particularly interested in issues of social justice. Wilma is on the Executive board of the International Research Association for Talent Development and Excellence and is chief editor of the international journal, Talent Development and Excellence. 